\title{
academicJournals
}

Vol. 10(2), pp. 106-116, February 2018

DOI: $10.5897 /$ IJBC2017.1124

Article Number: 79DF43F55541

ISSN 2141-243X

Copyright (C) 2018

International Journal of Biodiversity and

Author(s) retain the copyright of this article

Conservation

http://www.academicjournals.org/IJBC

\section{Impacts of waste on macroinvertebrate assemblages of Msimbazi River, Tanzania}

\author{
Moses Joel Shimba ${ }^{1,2^{\star}}$, Isabela Thomas Mkude ${ }^{3}$ and Fredrick Ekow Jonah ${ }^{4}$ \\ ${ }^{1}$ Department of Biotechnology and Bioinformatics, University of Dodoma, Dodoma, Tanzania. \\ ${ }^{2}$ Department of Conservation Biology, University of Dodoma, Dodoma, Tanzania. \\ ${ }^{3}$ Department of Environmental Studies, Open University of Tanzania, Dar Es Salaam, Tanzania. \\ ${ }^{4}$ Department of Fisheries and Aquatic Sciences, University of Cape Coast, Cape Coast, Ghana.
}

Received 30 June, 2017; Accepted 15 November, 2017

\begin{abstract}
The status of waste and its impact on macroinvertebrate assemblages along Msimbazi River was assessed between May 2014 and August 2014. The aim was to identify the type of waste, their potential sources, and the assemblage of macroinvertebrate taxa that have been affected by waste disposal in the river. The study involved field study and laboratory analysis. Results indicated that organic and inorganic waste are the main types of waste dumped into the river; industries and communities living adjacent and along the river are the main waste producers. Macroinvertebrates belonging to eight orders and 27 families were recorded. Macroinvertebrates of the Gastropoda and Diptera orders were the most dominant in occurrence of all macroinvertebrate taxa, contributing 27 and $21 \%$, respectively of the total macroinvertebrates. Based on macroinvertebrates sensitivity, 21 taxa $(77.77 \%)$ were identified as being highly tolerant to pollution, six taxa $(22.23 \%)$ as moderately tolerant and none of the most sensitive taxa. Macroinvertebrate diversity indices yielded a slightly lower Shannon-Weiner diversity index $\left(H^{\prime}=0.42\right)$ and the Shannon Evenness Index $(0.2050)$ amongst sites. These findings are indicative of disturbed systems whose severity seems to be driven by the on-going waste disposal within and along the river continuum.
\end{abstract}

Key words: Benthic macrofauna, diversity indices, organic waste, inorganic waste, pollution, waste management.

\section{INTRODUCTION}

Large scale pollution of rivers has resulted in strict enforcement of waste disposal legislation in most industrialized countries, where wastewater is to be disposed of only after the quality meets certain criteria.
This is in contrast to most developing countries where sewage goes untreated (Fakayode 2005; Bernhardt and Palmer, 2007; Kassenga and Mbuligwe, 2009; Mrutu et al., 2013). Rivers have a natural, though limited, capacity

*Corresponding author. E-mail: shimbamoses@yahoo.com; mosesshimba@udom.ac.tz.

Author(s) agree that this article remains permanently open access under the terms of the Creative Commons Attribution License 4.0 International License 
to restorewater quality to pre-pollution levels, through dilution, die-off, sedimentation and biological processes (Anyona et al., 2014). However, with the growth of cities, the amount of waste disposed into rivers often grows beyond their self-purifying ability (Fakayode, 2005; Kassenga and Mbuligwe, 2009). In these instances, untreated wastewater disposal poses serious risks to aquatic ecosystem health (Anyona et al., 2014; Elias et al., 2014).

Excessive loading of both industrial and domestic waste into rivers can alter the physical, chemical and biological characteristics of the aquatic system beyond their natural self-purification capacity. Higher levels of turbidity, nutrients, suspended and dissolved solids as well as coliform bacteria in rivers are all indicative of compromised systems attributed to increased pollutant load, resulting largely from anthropogenic activities (Adams and Papa, 2000). Such changes in water quality can alter the community structure of benthic macroinvertebrates and other aquatic biota therein (Boyle and Fraleigh, 2003).

Freshwater macroinvertebrate species are therefore at higher risk of extinction due to habitat degradation following overwhelming human activities (that is, invasive industrialization, agriculture, and urban development) near rivers (Jamil, 2001; L'ev'eque and Balian, 2005; Likens, 2010; Elias et al., 2014). It is unlikely that there is a substantial number of freshwater bodies remaining that have not been irreversibly altered from their original state as a result of anthropogenic activities (Elias et al., 2014). In Tanzania, for example, most of the industries are located in Dar es Salaam city and discharge their waste into Mzinga, Msimbazi, Yombo, and Kizinga rivers, which eventually flows into Indian Ocean (Ak'habuhaya and Lodenius, 1989; Kassenga and Mbuligwe, 2009; Mrutu et al., 2013; Elias et al., 2014). This, in turn, affects the occurrence, composition, and the distribution of freshwater macroinvertebrate species, depending on their levels of tolerance and adaptability (Suleiman and Abdullahi, 2011; Elias et al., 2014).

Tanzania is one of the richest countries in the world in terms of biodiversity and endemism (Lovett, 1998). In spite of its rich biodiversity, some areas, especially urban communities, are currently being threatened by pollution resulting from improper waste management. The Msimbazi River in Dar es Salaam is one such area that has been heavily polluted by domestic and industrial waste, thus negatively impacting the biodiversity and possibly resulting in the disappearance of certain plant and animal species (Mashauri and Mayo, 1989). Despite the ecological importance of Msimbazi River, few studies (Ak'habuhaya and Lodenius, 1989; Kassenga and Mbuligwe, 2009; Mwegoha et al., 2012; Mrutu et al., 2013) have been conducted on the ecological effects and current ecosystem health resulting from the continuous discharge of solid and liquid waste into the river.
The aim of this study was to identify the type of waste and provide information about the ecosystem health of the Msimbazi River using macroinvertebrates as ecological indicators. An overview of selected physicochemical conditions present in the river is also provided. This paper presents the findings of investigation on the effects of waste on macroinvertebrate taxon diversity and composition along the Msimbazi River, Tanzania.

\section{MATERIALS AND METHODS}

\section{Study site}

The study was conducted in the Msimbazi River, Tanzania. The river originates in Kisarawe highlands in the Coast-Pwani region of Tanzania, to the south-west of Dar es Salaam city. It flows between latitudes $6^{\circ} 48^{\prime}$ 51.3"S and $39^{\circ} 16^{\prime} 43.5^{\prime \prime} \mathrm{E}$ in a North-Easterly direction, and enters the Indian Ocean within the northern part of Dar es Salaam City (Figure 1).

The river has a wide flood plain (as wide as $1100 \mathrm{~m}$ ) in some areas and covers a total area of approximately $260 \mathrm{~km}^{2}$ (Hobbelen, 2001). The Msimbazi valley provides diverse ecological, socioeconomic and agricultural functions to residents of Dar es Salaam, a city with an estimated population of approximately 4 million people. The Msimbazi valley is an important ecological area, largely due to its extensive wetlands (Rwenyagira, 1988). Six sampling sites were selected along the river. Site SS1 was located in the upper Msimbazi River before industrial waste and sewage discharge points, and therefore serves as a reference point. Sites SS2, SS3 and SS4 were at the points of industrial waste discharge (midstream) while sites SS5 and SS6 were along the subcatchment (downstream) where wastes had already mixed thoroughly. A summary description of the sampling sites is provided in Table 1.

\section{Macroinvertebrate assessment}

Field surveys to collect macroinvertebrate data on the Msimbazi River took place from May 2014 to August 2014 at six established sampling sites, where 20 sampling stations at each site were sampled on a monthly basis. Six sites each were chosen along with the river continuum; three (SS2 - SS4) within the industrial area, to capture the contributions from the industries to water quality degradation, two sites (SS5 and SS6) were located along the subcatchment where wastes had already mixed thoroughly, one site (SS1) was on the upstream reach for comparison purposes. A total of 120 samples were thus taken on a monthly basis, totaling 480 samples during the course of the study.

Macroinvertebrates were sampled in a $100 \mathrm{~m}$ stream reach where benthic and free floating invertebrates were collected using a standard hand net $(0.3 \mathrm{~m}$ deep with $500 \mu \mathrm{m}$ mesh size) attached to a metal frame (area $0.625 \mathrm{~m}^{2}$ ) and handle (1.48 m long). The net was used to collect macroinvertebrates from the water column, mud, on stones and macrophytes. Each hand netting round took one minute. To avoid bias resulting from spatial variations or patchiness, three random samples were collected from each of the microhabitats by establishing a transect at each sampling reach, with five equally spaced points from which a sampling point was selected using random numbers. This procedure was replicated three times for each microhabitat, making nine samples per reach and samples were pooled to make one composite sample per habitat per station. Samples were emptied into a white tray where 
Table 1. Description of the sampling stations along the Msimbazi River.

\begin{tabular}{ll}
\hline Sampling station & Site description \\
SS1 & $\begin{array}{l}\text { The most upstream site before industrial and sewage discharge points with habitat } \\
\text { diversity (riffles, pools and runs) (reference site). There was overhead canopy along the } \\
\text { stream banks. }\end{array}$ \\
SS2 - SS4 & $\begin{array}{l}\text { These points located in an industrial area; they were located in the waste discharge } \\
\text { points (effluent streams) with limited habitat diversity (few pools). The river banks were } \\
\text { devoid of forest cover. }\end{array}$ \\
\hline SS5 - SS6 & $\begin{array}{l}\text { These sites were eroded and devoid of vegetation; they are situated along the sub } \\
\text { catchment where waste had already mixed thoroughly. The stream bed was made of } \\
\text { cobbles and boulders with some woody debris. The area was dominated with agricultural } \\
\text { and domestic activities. }\end{array}$ \\
\hline
\end{tabular}

large objects were removed by forceps and the samples were filtered into plankton net.

Mesohabitats, which are distinct areas within a stream that provide habitat heterogeneity and increase invertebrate diversity, were identified as either stream banks where roots were present, vegetation or submerged objects; substrate areas of glides, riffles and pools; or accumulated organic material in glides and riffles. Riffles and pools were sampled separately to account for habitat variations. The sampled materials were emptied into specimen containers and preserved in $70 \%$ alcohol for laboratory analysis at the University of Dar es Salaam. Macroinvertebrate samples were sorted and identified to family level using general invertebrate textbooks and identification manuals (Gerber and Gabriel, 2002; Day et al., 2003).

\section{Water quality assessment}

Water quality parameters such as dissolved oxygen and conductivity were measured in situ using a YSI 556 MPS Handheld Multi Parameter Instrument (YSI Incorporation, Yellow Spring, USA) and $\mathrm{pH}$ using a hand held $\mathrm{pH} / \mathrm{mV}$ meter (Model: SX 711). Additional water samples for total suspended solids analysis were collected in $1000 \mathrm{ml}$ bottles and refrigerated at low temperatures $\left(<4^{\circ} \mathrm{C}\right)$ for 24 $\mathrm{h}$ prior to laboratory analysis. Total suspended solids (TSS) were analyzed from water samples following methods outlined in APHA (1998) by filtering $50 \mathrm{ml}$ of the sample through a pre-weighed standard glass-fiber filter into a dry and pre-weighed evaporating dish.

The residue retained on the filter paper was dried to a constant weight while the filtrate in the evaporating dish was evaporated in an oven at 103 to $105^{\circ} \mathrm{C}$ for $1 \mathrm{~h}$. These were cooled in a desiccator and weighed. The cycle of weighing was repeated until a constant weight was obtained, after which TSS was calculated and presented in milligram per litre. All the analyses were conducted at the Department of Aquatic Sciences and Fisheries Laboratory at the University of Dar es Salaam.

\section{Identification of type of waste and their potential sources}

Data on the type of waste was obtained from both primary and secondary sources. Primary data was obtained using a structured questionnaire that served as the main source of information. Questionnaires were given to households to obtain information on the type of waste and their potential sources (Table 2). In addition, formal interviews were conducted with residents living along and adjacent to the river. The household samples for the study were drawn using systematic sampling whereby a house was selected randomly then after in every two households a sample for the study was selected. The households were picked in relation to where water samples were taken at the distance of $500 \mathrm{~m}$ from both sides of the sub-catchment. Various stakeholders including Dar Es Salaam Water Supply Company (DAWASCO) were also interviewed. A total of two hundred and thirty $(n=230)$ respondents were interviewed using questionnaires. The sampling units were obtained from four wards, located in two municipalities where the river crosses. The wards were Tabata in llala Municipal, and Kigogo, Mzimuni, and Magomeni in Kinondoni Municipality. Variables collected in the field included types of waste and their sources and residents' awareness of proper sewage disposal mechanisms and interest in environmental conservation.

\section{Data analysis}

Descriptive statistics presented as means and their standard deviations were used to summarize the data characteristics. Students't-test was used to establish differences among variables between sites. The Shannon-Wiener diversity index $\left(H^{\prime}\right)$, as described by Magurran (1988), was used to assess diversity as follows:

$H^{\prime}=\Sigma[(n / N) \times \ln (n / N)]$

Where $n=$ number of individuals of a taxon and $N=$ total number of individuals in the sample. An associated evenness $J^{\prime}=H^{\prime} / H^{\prime}$ max (Pielou, 1975) was also calculated, where $H^{\prime}$ max is the maximum possible value of $H^{\prime}$. The collected data from questionnaires were verified, coded, and later analyzed using Statistical Package for Social Science (SPSS).

\section{RESULTS}

\section{Macroinvertebrate taxa diversity and abundance}

Macroinvertebrates belonging to eight orders and 27 families were encountered in the samples collected from six sampling sites. Macroinvertebrates of the Gastropoda and Diptera orders were the most dominant of all 
Table 2. Questionnaires provided to households along the Msimbazi River.

\begin{tabular}{|c|c|c|}
\hline \multicolumn{3}{|l|}{ Section I. General information of respondents } \\
\hline \multicolumn{3}{|l|}{ Respondent information } \\
\hline $\begin{array}{l}\text { Name of district } \\
\text { Name of ward }\end{array}$ & Response & Code \\
\hline \multicolumn{3}{|l|}{ Name of street } \\
\hline \multirow{6}{*}{ Age } & $18-25$ & 1 \\
\hline & $25-33$ & 2 \\
\hline & $33-40$ & 3 \\
\hline & $40-47$ & 4 \\
\hline & $47-54$ & 5 \\
\hline & Above 54 & 6 \\
\hline \multirow{2}{*}{ Gender } & Male & 1 \\
\hline & Female & 2 \\
\hline \multirow{4}{*}{ Education } & Non & 1 \\
\hline & Primary & 2 \\
\hline & Secondary & 3 \\
\hline & College/University & 4 \\
\hline \multicolumn{3}{|l|}{ Section II. Questions } \\
\hline \multirow[t]{2}{*}{ Questions } & Answer & Code \\
\hline & Less than a year & 1 \\
\hline \multirow{3}{*}{ For how long you have been living in this area? } & Three years & 2 \\
\hline & Five years & 3 \\
\hline & More than five years & 4 \\
\hline \multirow{7}{*}{ What do you do to earn your living? } & Unemployed & 1 \\
\hline & Employed & 2 \\
\hline & Self-employed & 3 \\
\hline & Small businesses & 4 \\
\hline & Small medium enterprises & 5 \\
\hline & Urban agriculture & 6 \\
\hline & House wife/husband & 7 \\
\hline \multirow{2}{*}{ If you are self-employed what livelihood activities do you practice? } & Urban Agriculture & 1 \\
\hline & Livestock keeping & 2 \\
\hline \multirow{4}{*}{ Do you use water from the river? } & Never & 1 \\
\hline & Sometimes & 2 \\
\hline & Always & 3 \\
\hline & Hardly & 4 \\
\hline \multirow{3}{*}{ If yes; What do you use for? } & Drinking & 1 \\
\hline & Cooking & 2 \\
\hline & Cleanness (washing and mopping) & 3 \\
\hline
\end{tabular}


Table 2. Contd.

\begin{tabular}{lll}
\hline & Irrigation (gardens) & 4 \\
& Construction & 5 \\
& Recreational (swimming) & 6 \\
& Others & 7 \\
For the time you have lived here have you observed any changes in the & Yes & 1 \\
cleanness/ quality of water in the river? & No & 2 \\
& & 1 \\
If yes; what do you think is the cause of those changes? & Industrial waste discharge & 2 \\
& Domestic wastes & 3 \\
If the answer is industrial pollutants; does it affect macroinvertebrates & Population increase/ change & 4 \\
community structure? & Seswerages & 1 \\
& No & 2 \\
Wf the answer is Yes: How does it affect macroinvertebrates? & Abundance & 1 \\
What can be done to control industrial/domestic waste discharge into & Dater systems? & 2 \\
\hline
\end{tabular}

macroinvertebrate taxa, contributing 27 and $21 \%$, respectively of the total macroinvertebrates abundance (Table 3). However, Chironomidae accounted for $79 \%$ of the dipteran abundance along the river continuum.

In addition, Oligochaetes and Hirudinae (considered being pollution tolerant taxa) in the phylum Annelida were collected at all sampled sites. There were significant differences in abundance between sites $(p<0.001)$. When the 27 macroinvertebrate taxa were further divided into three arbitrary groups based on their sensitivity or pollution tolerance using Gerber and Gabriel (2002), 21 taxa $(77.77 \%)$ were identified as being highly tolerant to pollution (those taxa known to occur in severely polluted or disturbed streams) and six taxa $(22.22 \%)$ as moderately tolerant (those taxa that are found in streams with intermediate degrees of pollution or disturbance) (Table 4). Macroinvertebrate diversity indices yielded a slightly lower (0.42) Shannon-Weiner diversity index $\left(\mathrm{H}^{\prime}\right)$ between sites. Likewise, the Shannon Evenness Index was also low (0.2050) (Table 5) and still fell far below the ideal metric value of 1 which is indicative of similar proportions of all taxa in the system.

\section{Physico-chemical water quality parameters}

Table 6 presents the mean and standard deviations of various physico-chemical parameters between the sampled sites in the Msimbazi River. Dissolved oxygen (DO) levels ranged between 0.01 and $9.20 \mathrm{mg} / \mathrm{L}$. There 
Table 3. Macroinvertebrates from all sampling sites in the Msimbazi River (The numbers refers to occurrence of the taxonomic group).

\begin{tabular}{|c|c|c|c|c|c|c|c|c|c|c|}
\hline Taxonomic group & Family/class & SS1 & SS2 & SS3 & SS4 & SS5 & SS6 & Total & $\begin{array}{c}\% \text { contribution } \\
\text { (Family/class) }\end{array}$ & $\begin{array}{l}\% \text { contribution } \\
\text { (Taxa) }\end{array}$ \\
\hline \multirow{2}{*}{ Annelida } & Hirudinae & 20 & 17 & 14 & 10 & 5 & 2 & 68 & 7.3 & \multirow{2}{*}{13} \\
\hline & Oligochaeta & 12 & 14 & 10 & 8 & 4 & 5 & 53 & 5.7 & \\
\hline \multirow{2}{*}{ Ephemeroptera } & Caenidae & 0 & 0 & 0 & 0 & 2 & 2 & 4 & 0.4 & \multirow{2}{*}{3.5} \\
\hline & Baetidae & 8 & 20 & 0 & 0 & 0 & 0 & 28 & 3.0 & \\
\hline \multirow{8}{*}{ Hemiptera } & Veliidae & 0 & 0 & 0 & 0 & 1 & 3 & 4 & 0.4 & \multirow{8}{*}{7.1} \\
\hline & Pleidae & 0 & 0 & 0 & 0 & 1 & 1 & 2 & 0.2 & \\
\hline & Gerridae & 1 & 0 & 0 & 0 & 0 & 2 & 3 & 0.3 & \\
\hline & Corixidae & 3 & 2 & 0 & 0 & 0 & 1 & 6 & 0.6 & \\
\hline & Belostomatidae & 10 & 0 & 0 & 8 & 9 & 1 & 28 & 3.0 & \\
\hline & Naucoridae & 0 & 0 & 3 & 0 & 0 & 12 & 15 & 1.6 & \\
\hline & Nepidae & 0 & 0 & 0 & 5 & 0 & 2 & 7 & 0.8 & \\
\hline & Notonectidae & 0 & 0 & 0 & 0 & 1 & 0 & 1 & 0.1 & \\
\hline \multirow{3}{*}{ Coleoptera } & Dytiscidae & 0 & 4 & 7 & 0 & 0 & 7 & 18 & 1.9 & \multirow{3}{*}{6.5} \\
\hline & Elmidae & 9 & 0 & 0 & 0 & 8 & 9 & 26 & 2.8 & \\
\hline & Gyrinidae & 0 & 0 & 0 & 0 & 12 & 5 & 17 & 1.8 & \\
\hline \multirow{2}{*}{ Trichoptera } & Hydropsychidae & 0 & 0 & 15 & 12 & 5 & 8 & 40 & 4.3 & \multirow{2}{*}{5.6} \\
\hline & Ecnomidae & 0 & 0 & 8 & 0 & 0 & 4 & 12 & 1.3 & \\
\hline \multirow{4}{*}{ Odonata } & Corduliidae & 0 & 0 & 0 & 0 & 2 & 0 & 2 & 0.2 & \multirow{4}{*}{15.9} \\
\hline & Libellulidae & 0 & 5 & 3 & 0 & 0 & 7 & 15 & 1.6 & \\
\hline & Coenagrionidae & 30 & 15 & 28 & 8 & 17 & 0 & 98 & 11.0 & \\
\hline & Aeshnidae & 0 & 3 & 4 & 4 & 6 & 12 & 29 & 3.1 & \\
\hline \multirow{3}{*}{ Gastropoda } & Planorbinae & 28 & 20 & 18 & 19 & 17 & 0 & 102 & 11.0 & \multirow[t]{3}{*}{27} \\
\hline & Physidae & 22 & 17 & 10 & 12 & 8 & 20 & 89 & 9.6 & \\
\hline & Lymnaeidae & 8 & 19 & 13 & 9 & 0 & 11 & 60 & 6.4 & \\
\hline \multirow{2}{*}{ Diptera } & Chironomidae & 40 & 30 & 38 & 28 & 22 & 0 & 158 & 17 & \multirow{2}{*}{21.4} \\
\hline & Ceratopogonidae & 0 & 0 & 0 & 3 & 1 & 25 & 29 & 3.1 & \\
\hline
\end{tabular}


Table 3. Contd.

\begin{tabular}{|c|c|c|c|c|c|c|c|c|c|c|}
\hline & Simuliidae & 3 & 9 & 0 & 0 & 0 & 0 & 12 & 1.3 & \\
\hline $\begin{array}{l}\text { Total occurrence } \\
\text { *SS- Sampling station }\end{array}$ & & 194 & 155 & 171 & 126 & 141 & 139 & 926 & 100 & 100 \\
\hline
\end{tabular}

Were significant differences in DO levels between sites (Student's t-test, $\quad P<0.05)$. Electrical conductivity values ranged between 2350 and $11943 \mu \mathrm{S} / \mathrm{cm}$. Conductivity levels varied significantly between sites (Student's t-test, $\mathrm{P}<0.05$ ). $\mathrm{pH}$ ranged from 8.02 to 11.50 , with no significant difference in $\mathrm{pH}$ levels among sites (Student's t-test, $P>0.05$ ). There were no significant differences in TSS levels between sites (Student's t-test, $P=0.289$ ).

TSS concentrations in the range of 25 to 100 $\mathrm{mg} / \mathrm{L}$ is considered to represent moderate water quality, with an average concentration of $25 \mathrm{mg} / \mathrm{L}$ suggested as an indicator of unimpaired stream water quality (Nevers and Whitman, 2004). The concentrations of TSS recorded at the sampling sites are considered higher when assessed against the Tanzania Municipality and Industrial Effluents standards, and Tanzania Water Quality Standards (Table 6).

\section{Waste disposal regimes in place near the Msimbazi River}

Most respondents (67\%) disposed their domestic waste directly into the river, while only $33 \%$ claimed that they have other forms of waste disposal mechanisms which are not connected to the river. It was identified from the field survey that, several factors influence waste disposal into the river; approximately $20 \%$ of respondents noted that there were no disposal grounds available for their use, while approximately $15 \%$ of respondents observed that there are disposal sites, however these were inaccessible to them.

\section{Source of waste to Msimbazi River}

Based on the household survey, it was noted that most of the waste disposed into the river is from domestic sources, although waste from sanitation facilities and industries were also recorded.

\section{DISCUSSION}

The Msimbazi catchment is characterized by a variety of land uses, including agriculture for green vegetables and many manufacturing and processing companies such as breweries, food processing plants, textile industries, soap and detergent producers, footwear and rubber product industries, paper manufacturers, sand mining for construction, waste stabilization ponds and so on (M. Shimba and I. Thomas, Personal Observations). Observations made at sampling points showed that all sites were impacted, though to varying degrees. Anthropogenic activities contribute to water quality deterioration, impacting macroinvertebrate assemblages (Pallela, 2000). It was established that the most common solid waste disposal method among residents along Msimbazi River was open dumping, owing to a general lack of clearly demarcated waste disposal sites. Dumping of garbage along the river banks and in storm drains may have facilitated their transportation and subsequent deposition in the Msimbazi River, resulting in water quality degradation.

According to Inanc et al. (1998), Martin et al. (1998) and Mwenda (2014), surface water contamination within urbanized areas is attributed to solid and liquid waste resulting from anthropogenic activities and deposited either along the banks, in storm drains or directly into the river channel. Kassenga and Mbuligwe (2004) and Mwenda (2014), also identified uncontrolled disposal of solid waste and excreta from informal settlements along the river continuum, inappropriately sited disposal pits, blockages and/or breakages of sewer lines at major junctions, increased human activities and urban surface runoff as among the sources of pollution into the Msimbazi River. This is in agreement with the present study where highest proportions of solid waste were recorded at the upper part of Kigogo ward along Msimbazi River that was characterized by elevated anthropogenic activities. Emere and Narisu (2007) further reported that, sections of the river flowing through urbanized areas and informal settlements are highly prone to pollution owing to their proximity to numerous pollutant sources such as waste water discharge points, solid waste disposal sites, raw sewage spills, and urban runoffs.

The type of solid waste encountered along the banks of the Msimbazi River was typical of 
Table 4. Taxa of some common Benthic Macroinvertebrates recorded while sampling during the study, categorized in general groupings of pollution sensitivity (Adapted from Gerber and Gabriel, 2002).

\begin{tabular}{|c|c|c|c|c|}
\hline Taxonomic order & Family/class & $\begin{array}{l}\text { Highly tolerant to } \\
\text { pollution }\end{array}$ & $\begin{array}{c}\text { Moderately tolerant to } \\
\text { pollution }\end{array}$ & $\begin{array}{c}\text { Very low tolerance to } \\
\text { pollution }\end{array}$ \\
\hline \multirow{2}{*}{ Annelida } & Hirudinae & $\sqrt{ }$ & & \\
\hline & Oligochaeta & $\sqrt{ }$ & & \\
\hline \multirow{2}{*}{ Ephemeroptera } & Baetidae & $\sqrt{ }$ & & \\
\hline & Caenidae & & $\sqrt{ }$ & \\
\hline \multirow{4}{*}{ Odonata } & Aeshnidae & & $\sqrt{ }$ & \\
\hline & Coenagrionidae & $\sqrt{ }$ & & \\
\hline & Libellulidae & $\sqrt{ }$ & & \\
\hline & Corduliidae & & $\sqrt{ }$ & \\
\hline \multirow{3}{*}{ Coleoptera } & Dytiscidae & $\sqrt{ }$ & & \\
\hline & Gyrinidae & $\sqrt{ }$ & & \\
\hline & Elmidae & & $\sqrt{ }$ & \\
\hline \multirow{8}{*}{ Hemiptera } & Notonectidae & $\sqrt{ }$ & & \\
\hline & Pleidae & $\sqrt{ }$ & & \\
\hline & Nepidae & $\sqrt{ }$ & & \\
\hline & Belostomatidae & $\sqrt{ }$ & & \\
\hline & Gerridae & $\sqrt{ }$ & & \\
\hline & Veliidae & $\sqrt{ }$ & & \\
\hline & Corixidae & & $\sqrt{ }$ & \\
\hline & Naucoridae & $\sqrt{ }$ & & \\
\hline \multirow{3}{*}{ Diptera } & Chironomidae & $\sqrt{ }$ & & \\
\hline & Simuliidae & $\sqrt{ }$ & & \\
\hline & Ceratopogonidae & $\sqrt{ }$ & & \\
\hline \multirow{3}{*}{ Gastropoda } & Physidae & $\sqrt{ }$ & & \\
\hline & Lymnaeidae & & & \\
\hline & Planorbidae & $\sqrt{ }$ & & \\
\hline \multirow{2}{*}{ Tricoptera } & Hydropsychidae & $\sqrt{ }$ & & \\
\hline & Ecnomidae & & $\sqrt{ }$ & \\
\hline Total & & 21 & 6 & 0 \\
\hline Taxa \% of the total & & 77.7 & 22.22 & 0 \\
\hline
\end{tabular}

the ongoing activities in the immediate vicinity. Common sanitation facilities used in these areas are pit-latrines, which are constructed close to the river in such a way that all the contents are directly disposed of into the river. Due to the fact that the water table is high, the pits are not sunken too deep and large parts are above the ground.

The results of the present study conform to some previous studies on pollution of Msimbazi River and their major sources. For example, Pallela (2000) and Mwenda (2014) cited untreated domestic wastes, pit-latrine effluent, and industrial effluent as the major source of pollution in the Msimbazi River. Several industries were identified as potential point sources of sewage including the breweries, food processing and textile industries (I. Thomas, Personal Observation). Although Lakhani Textile Industries has its sewage directed to Vingunguti oxidation ponds, there has been allegations that it is the 
Table 5. Diversity of macroinvertebrates along Msimbazi River.

\begin{tabular}{lc}
\hline Parameter & Status \\
\hline Number of occurrence & 926 \\
Taxa richness (d) & 27 \\
Shannon-Weiner Diversity Index (H') & 0.42 \\
Shannon Evenness Index (E) & 0.2050 \\
\hline
\end{tabular}

main polluter of the river in recent times. This is due to the fact that the industries lack wastewater treatment facilities and perhaps the government is not much concerned with the issue of pollution control in this river ecosystem. The situation is worse, since the effluent from Vingunguti oxidation ponds is also discharged to the river on its way into the Indian Ocean. The Vingunguti oxidation ponds serve all industries along Nyerere road housing estate and most likely influences sites SS5 and SS6.

Changes in the water quality of streams can reflect increased nutrient loads associated with sewage discharge and probably, to a lesser degree and agricultural runoff (Gaufin and Tarzwell, 1956; Gaufin, 1958; Olive and Dambach, 1973). In this study, the observed decreases in dissolved oxygen levels from SS2 to SS6 indicated a potential increased organic load in the stream.

Macroinvertebrates comprising of 27 taxa were encountered along with the river continuum. The 27 taxa recorded were however relatively low compared to those that have been reported for other rivers in other parts of Tanzania, for example 48 taxa in Karanga River (Elias et al., 2014) and 96 taxa in Pangani River (Kaaya et al., 2015). The low taxa diversity and the dominance by few taxa (particularly pollution tolerant taxa) could have been due to poor water quality resulting from changes in physico-chemical parameters as well as nutrient levels contributed by increased solid waste and sewage disposal into the river channel. The dominance of pollution tolerant taxa i.e. (Chironomidae, Planorbidae and Coenagrionidae) over the sensitive and non-tolerant taxa could be a pointer to poor water quality along the river continuum.

According to Allan (1995), Cortes et al. (2002) and Hamada et al. (2002), distribution and assemblages of benthic macroinvertebrates may be attributed to small scale variability in a variety of water quality parameters. However, Sanseverino and Nessimian (1998), Nessimian et al. (2003), and Chatzinikolaou et al. (2006) established that pollution and excessive nutrient enrichment from anthropogenic sources, in particular sewage and solid waste, can affect benthic macroinvertebrates' trophic relationships as well as their habitats and thus change their community structure and composition. Adakole and
Annune (2003) reported that changes in physicochemical parameters can disrupt life and reproductive cycles of aquatic fauna, impact on food chain and migration patterns or worse still impose physiological stress on even the tolerant macroinvertebrates. According to Mhatre and Panthurst (1997), Bonada et al. (2006), Choudhary (2012) and Sharma et al. (2012), the continuous exposure of benthic macroinvertebrates communities to pollution changes their species composition in response to the magnitude, duration and frequency of the pollutants.

The physico-chemical conditions, taxa diversity and the number of taxa encountered during this study might be linked to degradation of Msimbazi River largely as a result of the discharge of untreated waste into various sections of the river. Chironomidae presence at sites SS2 to SS5 may be due to its ability to survive in a wide range of $\mathrm{pH}$ spectrum and anoxic conditions which were prevalent there (Choudhary, 2012; Sharma et al., 2012).

The sewage disposal at this point could have contributed to deterioration of its waters especially because, the area was not protected and wastewater could therefore contaminate the water. Studies also show that Chironomidae are common inhabitants of sewage polluted waters that are often rich in nutrients and poor in oxygen (Chakraborty and Das, 2006). Even though Chironomidae comprised a large portion of the macroinvertebrate taxa at all sites except at site SS6, it is likely that the species present were different, particularly between sites SS1 to SS4. Winner et al. (1980) recorded similar differences. If the same Chironomidae member occurred at all sites, their abundance in one site should have occurred in synchrony with the others.

Effects of the decline in water quality downstream of the Msimbazi River were also evident in other macroinvertebrate taxa (Hirudinae, Oligochaeta, Planorbinae and Physidae), which exhibited reduced taxa numbers. Differences in macroinveretebrate taxa between sites SS1 to SS4, SS5 and SS6 were probably related to water chemistry, since there was a gradual change in physico-chemical water characteristics to further down the catchment where sites are located. Studies have shown that in streams similar to the Msimbazi River, constant or decreasing numbers of macroinvertebrate taxa are observed along the gradient from upstream to downstream (Elias et al., 2014; Kaaya et al., 2015). The loss of taxa owing to man-related impacts on the stream environment was confirmed in the present study.

Taxa diversity has often been related to the stability of the environment (Kaaya et al., 2015). In this study, the macroinvertebrate communities were subjected to environmental stress (e.g. changes in water quality), which was less predictable and more severe at sites SS4, SS5 and SS6 than the other sites. The dominance of a few macroinvertebrate taxa resulted in variation in 
Table 6. Variation in the selected water quality parameters (Mean \pm SD) along Msimbazi River.

\begin{tabular}{lcccccc}
\hline Parameter (Unit) & SS1 & SS2 & SS3 & SS4 & SS5 & SS6 \\
\hline $\mathrm{pH}$ & $8.50 \pm 0.70$ & $8.60 \pm 0.50$ & $10.40 \pm 0.14$ & $11.50 \pm 0.12$ & $9.10 \pm 0.01$ & $8.02 \pm 0.11$ \\
$\mathrm{DO}(\mathrm{mg} / \mathrm{L})$ & $9.20 \pm 0.70$ & $0.90 \pm 0.22$ & $1.70 \pm 0.11$ & $0.10 \pm 0.17$ & $0.01 \pm 0.08$ & $3.00 \pm 0.18$ \\
$\mathrm{TSS}(\mathrm{mg} / \mathrm{L})$ & $328.7 \pm 2.0$ & $434.5 \pm 3.9$ & $738.0 \pm 2.10$ & $1727.50 \pm 5.3$ & $2240.0 \pm 4.5$ & $942.30 \pm 3.5$ \\
Conductivity $(\mu \mathrm{S} / \mathrm{cm})$ & $2350 \pm 20.1$ & $6870 \pm 2.12$ & $3080 \pm 2.5$ & $11943 \pm 5.8$ & $3500 \pm 7.55$ & $2509 \pm 4.3$ \\
\hline
\end{tabular}

+SS-Sampling station, •Permissible TSS (mg/L) by Tanzania Water Quality Standards [TZS 789:2008]: Released in May 2009 (Upper limit values) $=100, \bullet$ Permissible TSS (mg/L) by Tanzania Limits for Municipal and Industrial Effluents stipulated in Environmental Management (Water Quality Standards) Regulations, $2007=100$.

macroinvertebrate abundance at sites SS4 to SS6 Site SS2 recorded a higher abundance of Baetidae as compared to Site SS1. It is impossible to determine whether this increase resulted from successful reproduction at the site or from drift originating upstream. The latter explanation seems most probable, as macroinvertebrates from Baetidae were absent in sites SS3 to SS6. The other observed differences among the macroinvertebrate communities may have also been related to changes in water quality.

Continued accumulation of dissolved and suspended solids in aquatic systems reduces water transparency, effectively impacting on primary productivity, thus affecting benthic macroinvertebrates (Emere and Narisu, 2007). It can also clog gills of aquatic fauna (Edokpayi and Nkwoji, 2007) and destroy critical habitats by settling at the bottom of the water body, forming a blanket over critical spawning and breeding ground, thus interfere with the life cycle of aquatic organisms including macroinvertebrates. Increases in total suspended solids from SS1 to SS5 appeared to have detrimental effect on the macroinvertebrates. The overall low diversity of macroinvertebrates $\left(\mathrm{H}^{\prime}=0.42\right)$ reflected that, taxa composition was very different between sites; a fact that was observed by the dominance and abundance of pollution tolerant taxa (Chironomidae, Planorbinae and Coenagrionidae) over other taxa. In the present study, macroinvertebrates were not uniformly distributed along the river continuum, neither did they exhibit consistent increase or decrease downstream, but instead, varied between sites along the river continuum. This was partly caused by changes in water quality along the river continuum.

\section{Conclusion}

The Msimbazi River is partly impacted by waste disposal from nearby and fringing industries. A change in physicochemical water quality parameters, driven mainly by these practices along the river continuum influence macroinvertebrates. Our results suggest that some of the observed taxa are highly tolerant to pollution while others are moderately tolerant to pollution. These indicator taxa can be used in water-quality evaluation and in monitoring the recovery of streams in the study area.

Msimbazi River with habitat diversity has experienced significant impact as a result of the influx of sewage and chemicals and organic pollution disposed off in it, of which it contributed to the change in macroinvertebrates assemblages. Maintenance of ecological integrity by controlling anthropogenic activities, protection of the river channel and its basin and increased public education and awareness with regard to environmental integrity is therefore recommended.

\section{CONFLICT OF INTERESTS}

The authors have not declared any conflict of interests.

\section{ACKNOWLEDGEMENTS}

We would like to thank the Department of Aquatic Sciences and Fisheries, University of Dar es Salaam for allowing us to conduct the water quality assessment test and specimen identification. We wish to thank all the technicians who assisted us in the field and laboratory work and Mr. Makemie Mabula, a GIS specialist of Ilemela District Council for map making. We gratefully acknowledge the financial support of the Department of Environmental Studies, Open University of Tanzania, 2014.

\section{REFERENCES}

Adakole JA, Annue PA (2003). Benthic Macroinverteberates as indicators of Environmental quality of an urban stream, Zaria, Northern Nigeria. J. Aquat. Sci. 18:85-92.

Adams BJ, Papa F (2000). Urban storm water management planning with analytical probabilistic models. Ontario, Toronto, Canada: Wiley.

Ak'habuhaya J, Lodenius M (1989). Metal pollution of River Msimbazi, Tanzania. Environ. Int. 14:511-514.

Allan JD (1995). Stream Ecology: Structure and Function of Running Waters. London: Chapman and Hall.

Anyona DN, Abuom PO, Dida GO, Gelde FB, Onyuka JO, Matano AS, 
American Public Health Association (APHA) (1998). Standard Methods for the Examination of Water and Wastewater, American Public Health Association,Washington, D.C., USA, 20th edition.

Bernhardt ES, Palmer MA (2007). Restoring streams in an urbanizing world. Freshw. Biol. 52:738-751.

Bonada N, Prat N, Resh VH, Statzner B (2006). Developments in aquatic insect biomonitoring: A comparative analysis of recent approaches. Annu. Rev. Entomol. 51:495-523.

Boyle TP, Fraleigh HD (2003). Natural and anthropogenic factors affecting the structure of the benthic macroinvertebrate community in an effluent-dominated reach of the Santa Cruz River. Ecol. Indic. 3:93-117.

Chakraborty D, Das SK (2006). Alteration of macroinvertebrate community in tropical aquatic systems in relation to sediment redox potential and overlaying water quality. Int. J. Environ. Sci. Technol. 2:327-334.

Chatzinikolaou Y, Dakos V, Lazaridou D (2006). Longitudinal impacts of anthropogenic pressures on benthic macroinvertebrate assemblages in a large transboundary Mediterranean river during the low flow period. Acta hydrochimica et Hydrobiologica 34:453-463.

Choudhary R (2012). Heavy Metal Analysis of Water of Kaliasote Dam of Bhopal, MP, India. Res. J. Recent Sci. 1:352-353.

Cortes RMV, Ferreira MT, Oliveira SV, Oliveira D (2002). Macroinvertebrate community structure in a regulated river segment with different flow conditions. River Res. Appl. 18:367-382.

Day JA, Harrison AD, de Moor IJ (2003). Guides to the freshwater invertebrates of southern Africa (Vols. 1-9). WRC Report No. TT 201/02. Pretoria: Water Research Commission.

Edokpayi CA, Nkwoji JA (2007). Annual changes in the physicochemical and macrobenthic invertebrate characteristics of the Lagos lagoon sewage dump site at Iddo, Southern Nigeria. Ecol. Environ. Conserv. 13:13-17.

Elias JD, ljumba JN, Mamboya FA (2014). Effectiveness and compatibility of non-tropical biomonitoring indices for assessing pollution in tropical rivers-a review. Int. J. Ecosyst. 4:128-134.

Emere MC, Narisu CE (2007). Macroinvertebrates as indicators of water quality of an urbanized stream in Kaduna, Nigeria. J. Fish. Int. 2:152157.

Fakayode SO (2005). Impact of industrial effluents on water quality of the receiving Alaro River in Ibadan, Nigeria. Ajeam-Ragee 10:1-13.

Gaufin AR (1958). The effects of pollution on a midwestern stream. Ohio J. Sci. 58:197-208.

Gaufin AR, Tarzwell LM (1956). Aquatic macroinvertebrate community as indicators of organic pollution in Lytle Creek. Sewage Industrial Wastes 28:906-924.

Gerber A, Gabriel MJM (2002). Field Guide to the Aquatic Invertebrates of South African Rivers. First Edition. Resource Quality Services. Department of Water Affairs and Forestry. South Africa.

Hamada NJ, Mccreadie W, Adler PH (2002). Species richness and spatial distribution of blackflies (Diptera:Simuliidae) in streams of Central Amazonia, Brazil. Freshw. Biol. 47:31-40.

Hobbelen HPM (2001). Assessment of Domestic Liquid Waste Runoff, Dar es Salaam, Tanzania. Application in rapid assessment for running water bodies. MSc. Thesis, Eindhoven University of Technology, Netherlands.

Inanc B, Kinaci C, Ozturk I, Sevimli MF, Arikan O, Ozturk M (1998). Pollution Prevention and Restoration in the Golden Horn of Istanbul. Water Sci. Technol. 37:129-136.

Jamil K (2001). Bioindicators and Biomarkers of Environmental Pollution and Risk Assessment, Science Publishers, Enfield, NH, USA,

Kaaya LT, Day JA, Dallas HF (2015). Tanzania River Scoring System (TARISS): A macroinvertebrate-based biotic index for rapid bioassessment of rivers. Afr. J. Aquat. Sci. 40:109-117.

Kanangire CK, Bosire EK, Oindo BO, Owuor PO, Ofulla AVO (2014). Effect of Anthropogenic Activities on Physicochemical Parameters and Benthic Macroinvertebrates of Mara River Tributaries, Kenya. Merit Res. J. Environ. Sci. Toxicol. 2:098-109.

Kassenga GR, Mbuligwe SE (2004). Feasibility and Strategies for Anaerobic Digestion of Solid Waste for Energy Production in Dar es Salaam City, Tanzania. Resour. Conserv. Recycl. 42:183-203.
Kassenga GR, Mbuligwe SE (2009). Impacts of a Solid Waste Disposal Site on Soil, Surface Water and Groundwater Quality in Dar es Salaam City, Tanzania. J. Sustain. Dev. Afr. 10(4):73-94.

L'ev'eque C, Balian EV (2005). Conservation of freshwater biodiversity: does the real world meet scientific dreams? Hydrobiologia 542:23-26.

Likens GE (2010). Lake Ecosystem Ecology, San Diego, Calif, USA, Academic Press.

Lovett JC (1998). Eastern Tropical African Center of Endemism: A Candidate for World Heritage Status? J. East Afr. Nat. Hist. 87:359366.

Magurran A (1988). Ecological diversity and its measurement. London: Croom Helm.

Martin JC, Hoggart C, Matissa A (1998). Improvement priorities for sewage treatment in latvian small and medium sized towns. Water Sci. Technol. 37:137-144.

Mashauri DA, Mayo A (1989). The Environmental impact of industrial and domestic wastewater in Dar es Salaam. In: Symposium on Environmental Pollution and Management in Eastern Africa. Faculty of Science, University of Dar es Salaam. 11-14 September 1989, pp. 90-101.

Mhatre GN, Panthurst CE (1997). In: C.E, Panthurst, B.M. Double, V.V.S.R Gupta (Eds), Biological indicators of soil health, Bioindicators to detect contamination of soils with special reference to heavy metals, CAB Intl. pp. 349-369.

Mrutu A, Nkotagu HH, Luilo GB (2013). Spatial distribution of heavy metals in Msimbazi River mangrove sediments in Dar es Salaam coastal zone, Tanzania. Int. J. Environ. Sci. 3:1641-1655.

Mwegoha WJS, Leonard LS, Kihampa C (2012). Heavy metal pollution and urban agriculture in the Msimbazi River Valley. Health Risk and public awareness. Int. J. Plant Anim. Environ. Sci. 2:107-118.

Mwenda A (2014). Levels of industrial pollutants and their effects on water resources and livelihoods along Msimbazi sub catchment- Dar es Salaam, Tanzania. MSc. Thesis. Kenyatta University, Kenya.

Nessimian JL, Amorim RM, Henriques-Oliveira AL, Sanseverino AM. 2003. Chironomidae (Diptera) do Estado do Rio de Janeiro: Levantamento dos ge^neros e habitat de ocorre^ncia. Publicac,o^ es Avulsas do Museu Nacional 98:1-16.

Nevers MB, Whitman RL (2004). Characterization and comparison of phytoplankton in selected lakes of five Great Lakes area national parks. Aquat. Ecosyst. Health Manag. 7:515-528.

Olive JH, Dambach CA (1973). Benthic macroinvertebrates as indexes of water quality in Whetstone Creek, Morrow County, Ohio (Scioto River Basin). Ohio J. Sci. 73:129-149.

Pallela E (2000). The impact of anthropogenic factors on urban Wetlands; The case of Msimbazi Valley, MSc. Thesis, University of Dar es Salaam, Tanzania.

Pielou EC (1975). Ecological diversity. New York: Wiley \& Sons.

Rwenyagira VEK (1988). Management of Msimbazi Basin, Dar es Salaam. Dar es Salaam, Tanzania: Department of Environmental Engineering, University College of Lands and Architectural Studies (UCLAS), Dar es Salaam, Tanzania.

Sanseverino A, Nessimian JL (1998). Habitat preference of Chironomidae larvae in an upland stream of Atlantic Forest, Rio de Janeiro State, Brazil. Verhandlungen Internationale Vereiningang fu“ $r$ Theoretische und Angewandte Limnologie 26:2141-2144.

Sharma P, Fulekar MH, Pathak B (2012). E-Waste-A challenge for tomorrow. Res. J. Recent Sci. 1:86-93.

Suleiman K, Abdullahi IL (2011). Biological assessment of water quality: a study of Challawa river water in Kano, Nigeria. Bayero J. Pure Appl. Sci. 4:121-127. 